\title{
Aerostat for Solar Power Generation
}

\author{
G. S. Aglietti, S. Redi, A. R. Tatnall, T. Markvart and S.J.I. Walker \\ University of Southampton \\ United Kingdom
}

\section{Introduction}

One of the major issues in the use of ground based photovoltaic (PV) panels for the large scale collection of solar energy is the relatively low energy density. As a result a large area is required on the ground to achieve a significant production. This issue is compounded by the fact that the power output of the devices is strongly dependent on the latitude and weather conditions. At high latitudes the sun is relatively low on the horizon and a large part of the solar energy is absorbed by the atmosphere. Countries situated at high latitudes, with climates such as the UK, are therefore challenged in their exploitation of solar energy as the average number of Peak Solar Hours (PSH - numerically equal to the daily solar irradiation in $\mathrm{kWh} / \mathrm{m}^{2}$ ) is relatively low. In Europe, typical annual average PSH values for horizontal surfaces range from about $2.5 \mathrm{~h}$ in northern England to $4.85 \mathrm{~h}$ in southern Spain (Markvart \& Castañer, 2003). As, roughly speaking, the cost of the energy produced is inversely proportional to the average PSH, northern European countries are at a considerable economical disadvantage in the exploitation of solar energy with respect to other regions. On the other hand, areas with high ground solar irradiations (e.g. African deserts, see Kurokawa, 2004) are remote from most users and the losses over thousands of miles of cables and the political issues entailed in such a large project, severely reduce the economic advantages.

A different approach to address most of the shortcomings of ground based solar energy production was proposed by Glaser et al., 1974 and his idea has captured the imagination of scientists up to this day. The basic concept was to collect solar energy using a large satellite orbiting the Earth. This satellite would be capable of capturing the full strength of the solar radiation continuously and transmit it to the ground using microwave radiation. The receiving station would then convert the microwave radiation into electric energy for widespread use.

The original concept was revisited in the late 90's (Mankins, 1997) in view of the considerable technological advances made since the 70's and research work on this concept is still ongoing. However a mixture of technical issues (such as the losses in the energy conversions and transmission), safety concerns (regarding the microwave beam linking the satellite with the ground station) and cost have denied the practical implementation of this concept. The latter is a substantial hurdle as the development of Satellite Solar Power (SSP) cannot be carried out incrementally, in order to recover part of the initial cost during the development and use it to fund the following steps, but it requires substantial funding upfront (tens of billions of dollars according to Mankins, 1997) before there is any economical return. 
As a compromise between Glaser's (SSP) and ground based PV devices it is possible to collect the solar energy using a high altitude aerostatic platform (Aglietti et al., 2008a, b). This approach allows most of the weather related issues, except for very extreme weather conditions, to be overcome as the platform will be above the cloud layer. As the platform is also above the densest part of the troposphere, the direct beam component from the sun will travel through considerably less air mass than if it was on the ground (in particular for early morning and evening) and this will further improve the energy output. Therefore this method enables considerably more solar power to be collected when compared to an equivalent ground based system. In addition, the mooring line of the platform can be used to transmit the electric energy to the ground in relative safety and with low electrical losses. Although this approach would capture between $1 / 3$ and $1 / 2$ of the energy that could be harvested using a SSP, the cost of the infrastructure is orders of magnitude lower, and this approach allows an incremental development with a cost to first power that is a few orders of magnitudes smaller than that necessary for SSP.

Most researchers up till now have proposed harvesting energy at high altitude by exploiting the strong winds existing in the high atmosphere such as the jet streams (Roberts et al., 2007). This would be achieved using Flying Electrical Generators, that are essentially wind turbines collecting wind power at altitudes from few hundred meters (www.magenn.com) to over $10 \mathrm{~km}$.

The extraction of this energy using the type of machines proposed by Roberts et al. 2007, although feasible and most probably economically viable, is relatively complex in mechanical terms. One of the issues is that in low wind the machine (that is heavier than air) needs to reverse its energy flow and take energy from the ground to produce enough lift to support itself and the tether. Alternative designs like the MAGENN (www.magenn.com) overcome this problem using a lighter-than-air approach so that the buoyancy keeps it in flight all the time. However the mechanical complications are still considerable.

The exploitation of solar energy at high altitude may therefore be simpler in engineering/mechanical terms, and provide a very predictable/reliable source. One of the crucial steps to demonstrate the viability of the concept is a reliable calculation of the solar energy available as a function of the altitude. After a brief introduction on aerostatic platforms, the energy available at different altitudes is investigated. The concept of the Aerostat for Solar Power Generation (ASPG) is then described together with the equations that link its main engineering parameters/variables, and a preliminary sizing of an ASPG, based on realistic values of the input engineering parameters is presented.

\section{Aerostatic platforms}

Lighter-than-air craft (aerostats) have been progressively neglected by the main stream research in Aerospace Engineering during the second half of the past century after having made remarkable technological progress that culminated in the 1930's with the construction of over 200m long airships (Dick \& Robinson, 1992, Robinson, 1973). There have been some developments of historical interest (Kirschner, 1986) but little of significance.

However, in the last few years, aerostats have attracted a renewed interest. Their typical market niches (scientific ballooning, surveillance/reconnaissance (Colozza \& Dolce, 2005)) are expanding and more researchers have proposed several different applications, ranging from high altitude aerostats as astronomical platforms (Bely \& Ashford, 1995) to infrastructures for communication systems (Badesha, 2002). 
Amongst the most recent achievements in scientific ballooning are the Ultra-High Altitude Balloon (UHAB) developed for NASA (launched in 2002 with a volume of nearly 1.7 million cubic metres and reached an altitude of $49 \mathrm{~km}$ ) and the ultra-thin film high altitude balloon constructed by the Institute of Space and Astronautical Science (ISAS) of Japan, which successfully carried a $10 \mathrm{~kg}$ payload to a world-record altitude of $53 \mathrm{~km}$.

Tethered aerostats are limited to lower altitudes due to the weight of the tether, which increase linearly with height. Commercial aerostats fly up to $8 \mathrm{~km}$ but various studies have been conducted to prove that considerably greater altitudes can be reached. For example the Johns Hopkins University Applied Physics Laboratory (JHU/APL) has conducted a successful feasibility study (although not experimentally demonstrated) on a high altitude $(20 \mathrm{~km})$ tethered balloon-based space-to-ground optical communication system (Badesha, 2002). The US Airforce has made extensive use of aerostats as a surveillance system, and there are aerostats available on the market like the Puma Tethered Aerostat (www.rosaerosystems.pbo.ru) or the TCOM's 71M (www.tcomlp.com) that can fly up to approximately $5 \mathrm{~km}$ tethered with payloads of $2250 \mathrm{~kg}$ and $1600 \mathrm{~kg}$ respectively. These aerostats have a mooring cable (i.e. their tether) that supplies the aerostat onboard systems and the payload with electric power, and they are designed to be able to withstand lightning strikes and strong winds.

Concerning the size, today's airships are considerably smaller than those constructed in the 1930 's and that is mainly due to the economics of their typical functions. However, from a technical point of view, the state of the art in the relevant technologies would allow the construction of aerostats much larger than those currently in operation.

The possibility of using solar power as source of energy for the airship propulsion and/or to supply energy to on board systems has been investigated by Khoury and Gillett, 2004. The "sunship" that he proposed was a very simple and conventional envelop design, filled with helium, with thin film solar arrays covering appropriate areas of the external surface. The electrical power produced by the cells was then used for the propulsion and on board electrical system, with part of the energy stored in suitable units with high storage energy to weigh ratio. Notwithstanding the quality of the case made by the author, the "sunship" was never built.

However changes in the economy, driven by politics and/or technical factors (limitation of resources or scientific advances) transform the markets and the viability of certain technologies may change as a result. A typical case is that of wind turbines, whose technology has been available for decades, but only in the last few years have become a viable method to produce large quantities of electric energy.

\section{High altitude solar radiation}

The first step in the development of the ASPG concept is to evaluate how much solar energy is available as a function of altitude. This allows a direct assessment of the potential of the ASPG when compared to an equivalent ground based system.

This section presents a set of calculations to enable this comparison and considers the possible influence of cloud layers at different heights above the ground (up to $12 \mathrm{~km}$ ). The results obtained are based on existing models for ideal clear sky conditions and are integrated with experimental data acquired by scientific instrumentation at a specific site in the south of the United Kingdom. Although this makes the analysis very location specific, the general conclusions about the potential of high altitude solar collectors can be extended 
to other countries at similar latitudes and with similar climatic conditions. Moreover it must be noted that the assumptions made in the calculation process are quite conservative in order to avoid a possible overestimate of the potential of the ASPG concept.

The attenuation that a solar beam experiences as it travels through the atmosphere is called extinction and it is mainly due to two different kinds of processes, absorption and scattering, the former being the conversion of photon energy into thermal energy and the latter involving the deflection of the photons after the interaction with atmospheric molecules or larger particles suspended in the air. These two processes cause the radiation falling on a surface to be divided into two components: direct (or beam) and diffuse. The contribution of the diffuse radiation becomes proportionally more important when the collector is located at lower altitudes, in particular under cloudy sky conditions.

Since several models that describe the characteristics of the clear atmosphere at various altitudes have been developed in the past, existing publications can be considered when dealing with these conditions. Some of these models have also been embedded in specific software (such as SMARTS (Donovan \& Van Lammeren, 2001) hosted by the National Renewable Energy Laboratory), which are widely used now as design tools in the PV industry. For the present purposes the sky is considered clear above an altitude of $12 \mathrm{~km}$, since it is rare to find clouds at higher layers of the atmosphere and the impact on the final results is assumed to be minimal. Therefore, the clear sky radiation falling on a sun tracking surface at $12 \mathrm{~km}$ can be directly determined with the use of SMARTS (Gueymard, 1995) using the site location and time of year as inputs. For the initial calculations only the beam contribution of the solar radiation is included in the analysis.

The influence of clouds is incorporated into the calculation process using the extinction parameter, determined from experimental data. The data used was acquired by radar/lidar systems (www.cloud-net.org) at a station located at Chilbolton Observatory (51.1445 N, $1.4370 \mathrm{~W}$ ) in the South of the UK. These experimental measurements have been elaborated (see Redi 2009) to provide the extinction parameter profile in actual sky conditions, which relates the attenuation of the solar radiation to its path through the atmosphere, considering the possible presence of cloud layers. The observations were performed almost everyday of the year (from April 2003 to September 2004), 24 hours a day, in the height range between 0 and $12 \mathrm{~km}$. Averaging the data for the different layers of the atmosphere and in different months of the year, it is possible to obtain the extinction parameter profile at various altitudes above the ground. As an example the values obtained for the month of March is presented in Fig. 1.

Having determined the extinction parameter the Lambert-Beers' attenuation law (Liou, 2002) can be used to calculate the loss of intensity of a solar beam as it travels through the atmosphere. By dividing the atmospheric path along the vertical in segment of length $\Delta h_{i}$ and defining the extinction parameter for each segment $\alpha_{i}\left(\mathrm{~m}^{-1}\right)$, the variation of intensity $I$ (the irradiance in $\mathrm{W} / \mathrm{m}^{2}$ ) can be expressed as:

$$
I\left(\vartheta_{Z}\right)=I_{12 k m} \exp \left(-A M_{R E L}\left(\vartheta_{Z}\right) \cdot \sum\left(\alpha_{i} \cdot \Delta h_{i}\right)\right)
$$

where $I_{12 \mathrm{~km}}$ is defined as the solar irradiance at $12 \mathrm{~km}$ estimated with SMARTS and $A M_{R E L}\left(\vartheta_{Z}\right)$ is the relative air mass, which describes the path length relative to that at the Zenith and it is therefore a function of the solar Zenith angle $\vartheta_{z}$. 


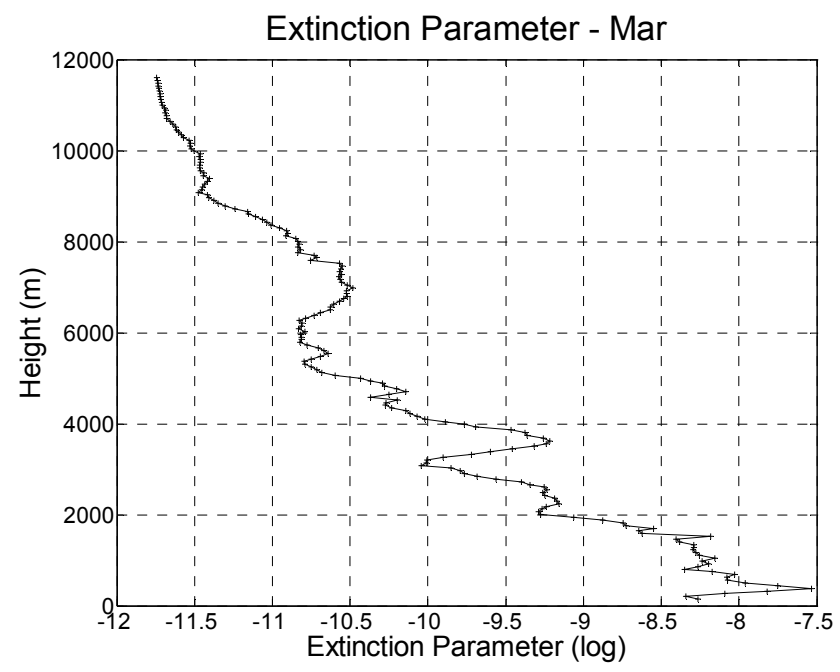

Fig. 1. Daily Mean Extinction (log) for the month of March - Chilbolton Observatory (51.1445 $\mathrm{N}, 1.4370 \mathrm{~W}$ )

Models like MODTRAN (Berk et al., 1989) or LibRadtran (Mayer \& Kylling, 2005) that are able to integrate information about the cloud structure with the clear sky data, could be considered as a more accurate alternative to the one proposed here. However these models are quite sophisticated and they are generally more oriented towards atmospheric physics studies rather than engineering ones.

Starting from the irradiance values obtained with SMARTS at $12 \mathrm{~km}$, Eq. 1 is applied to the extinction parameter values in actual sky for different months, in order to get an estimate of the irradiance below an altitude of $12 \mathrm{~km}$ in atmospheric conditions including possible clouds. The results obtained for the month of March at $12 \mathrm{~km}, 6 \mathrm{~km}$ and on the ground are presented in Fig. 2.

As a final step, it is necessary to integrate the irradiance values during the day (from sunrise to sunset) to calculate the total beam energy (beam irradiation $E_{B}$ ) falling on the high altitude solar collector:

$$
E_{B}(h)=\int_{S R}^{S S} I_{B}(h) d t
$$

where $S S$ and $S R$ are the time of Sunset and Sunrise.

The total beam energy can now be used to evaluate the potential of the ASPG system when compared to an equivalent ground based PV array.

Considering an altitude of $6 \mathrm{~km}$, and integrating graphs like the ones shown in Fig. 3 gives value of about $3600 \mathrm{kWh} / \mathrm{m}^{2}$ for the energy reaching the sun tracking platform in one year. It must be noticed that due to various conservative assumptions in the calculations this shoud be a rather conservative estimate. A general overview of the beam energy that can be collected by a platform located at an altitude up to $12 \mathrm{~km}$ is provided in Table 1. 


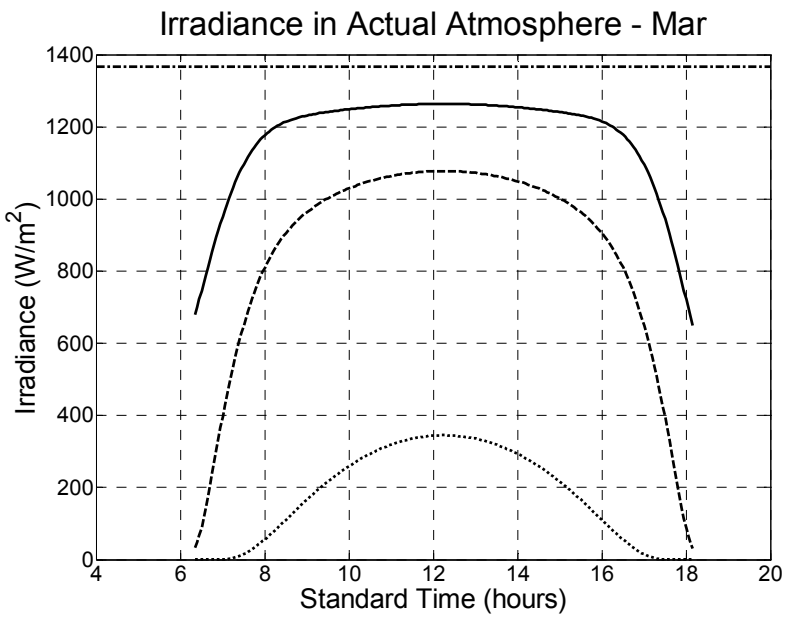

Fig. 2. Irradiance at $12 \mathrm{~km}$ (solid line), and at $6 \mathrm{~km}$ (dashed line) and on the ground (dotted line) including possible clouds, solar constant (dash-dotted line) - Chilbolton Observatory $(51.1445 \mathrm{~N}, 1.4370 \mathrm{~W})$

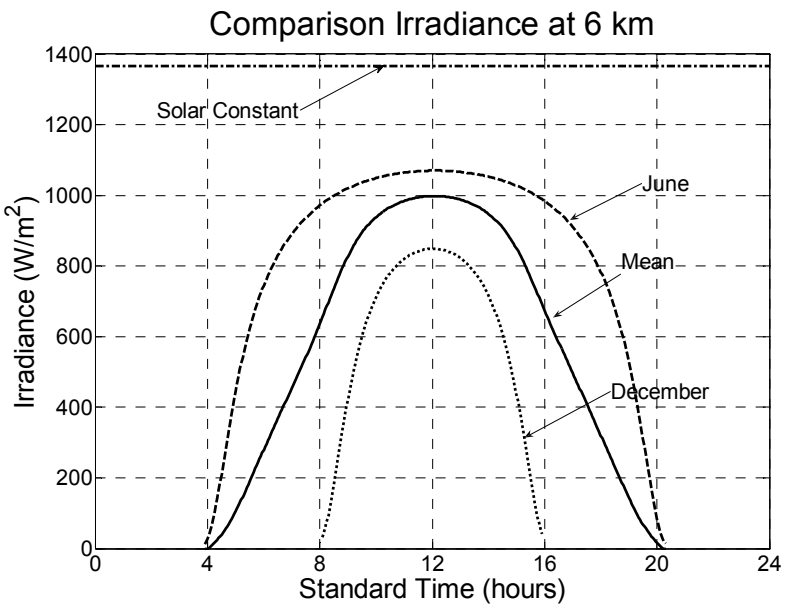

Fig. 3. Comparison between irradiance at $6 \mathrm{~km}$ for different monthly means - Chilbolton Observatory $(51.1445 \mathrm{~N}, 1.4370 \mathrm{~W})$

\begin{tabular}{|c|c|c|}
\hline Altitude $[\mathrm{km}]$ & $\begin{array}{c}\text { Total Year Beam Irradiation } \\
\text { (including possible clouds/) } \\
{\left[\mathrm{kWh} / \mathrm{m}^{\wedge} 2\right]}\end{array}$ & $\begin{array}{c}\text { Total Year Beam } \\
\text { Irradiation (clear sky) } \\
{\left[\mathrm{kWh} / \mathrm{m}^{\wedge} 2\right]}\end{array}$ \\
\hline 6 & 3600 & 4530 \\
\hline 9 & 4710 & 4800 \\
\hline 12 & 5310 & 5310 \\
\hline
\end{tabular}

Table 1. Year Beam Irradiation at different altitudes - Chilbolton Observatory (51.1445 N, $1.4370 \mathrm{~W})$ 
The study has been focused so far on the evaluation of the beam (direct) component of the solar radiation that can reach the surface. However, the contribution of the diffuse part of the radiation can be not negligible. Having considered this, the contribution of the diffuse radiation is estimated at different altitudes, with the use of SMARTS in ideal clear sky conditions. This assumption is expected to be extremely conservative since clouds can increase significantly the amount of this component which can become therefore higher particularly if actual sky conditions are considered.

The ratio between diffuse and global irradiation is estimated to range from about $5 \%$ (12 $\mathrm{km})$ to $6 \%(6 \mathrm{~km})$. This contribution is then summed to the values presented in Table 1, leading to the determination of the total radiation reaching a sun pointing surface located at an altitude up to $12 \mathrm{~km}$ which is presented in Table 2. Here, the comparison between the results obtained and the typical irradiation value expected for a PV array based on the ground (facing south and tilted at a fixed angle close to the latitude of its location) is given. The value of the energy collected by the solar power satellite (Glaser et al., 1974) is also included as a limit solution.

In addition to the contribution of the diffuse component of the solar radiation, some considerations about the albedo flux should be made. Considering that the albedo radiation factor can reach a value of $10 \%$ for a satellite in Low Earth Orbit (Jackson, 1996), this component can significantly contribute to the total radiation estimate. In our specific case it is difficult during this preliminary analysis to give an estimate of this component with a sufficient degree of confidence. It must be noticed though, as a caveat, that the values presented in Table 2 are conservative and they are expected to increase when the albedo is included, especially in presence of cloud layers below the platform when the sun is at high zenith angles.

\begin{tabular}{|c|c|c|}
\hline Altitude $[\mathrm{km}]$ & $\begin{array}{c}\text { Year Global Irradiation } \\
\text { including clouds } \\
\text { (conservative estimate) } \\
{\left[\mathrm{kWh} / \mathrm{m}^{2}\right]}\end{array}$ & $\begin{array}{c}\text { Year Global Irradiation } \\
\text { (clear sky) } \\
{\left[\mathrm{kWh} / \mathrm{m}^{2}\right]}\end{array}$ \\
\hline Ground Based (Chilbolton) & 1150 & 4819 \\
\hline 6 & 3830 & 5080 \\
\hline 9 & 4985 & 5590 \\
\hline 12 & 5590 & \\
\hline Solar Power Satellite & 12000 & \\
\hline
\end{tabular}

Table 2. Comparison between the year global irradiation (including diffuse) values at different altitudes for Chilbolton Observatory (51.1445 N, 1.4370 W)

The results obtained can give a preliminary idea of the gain that a high altitude solar generator could bring in terms of energy collected, if compared to the same generator located on the ground.

Due to the very conservative assumptions the values in the first column can be considered as "minimum" values, and the one in the last column as maximum, although the inclusion of the albedo should give results even higher.

Moreover a collector placed at an altitude of $12 \mathrm{~km}$ could collect around $45 \%$ of what could be collected by the same PV system in a geostationary position (i.e. Solar Power Satellite).

The study presented is preliminary and it involves several assumptions that have been made to simplify the analysis and provide useful results to support the following phases of 
the project. In particular the extinction parameter data used are acquired in a defined and limited time period and they are relative to a precise location in the south of the UK, which is relatively well placed to collect solar energy on the ground. For this reason and the other discussed previously, the figures presented are conservative and the advantage with respect to ground installations is expected to increase as installations at northern latitude are considered and the values concerning the estimate of the diffuse and albedo contributions are revised.

\section{High altitude winds}

The knowledge of the mean wind speed at a certain altitude (and its statistical properties) is essential to calculate the aerodynamic forces acting on the aerostat and in particular to determine the forces along the mooring cable.

The wind speed data described in this section were provided by the Natural Environment Research Council (NERC), from the Mesosphere-Stratosphere-Troposphere (MST) Radar station located at Capel Dewi $\left(52.42^{\circ} \mathrm{N}, 4.01^{\circ} \mathrm{W}\right)$, near Aberystwyth in west Wales (UK). This facility can provide vertical and horizontal wind speed data, covering an altitude range from 2 to $20 \mathrm{~km}$, with $300 \mathrm{~m}$ resolution. However for this study only the data up to $10 \mathrm{~km}$ were processed. The particular set of data described here covers the period JanuaryDecember 2007 and measurements were acquired every day continuously. The radar is located near the coast, where the wind speed is expected to be slightly higher than inland and therefore the estimate should be conservative.

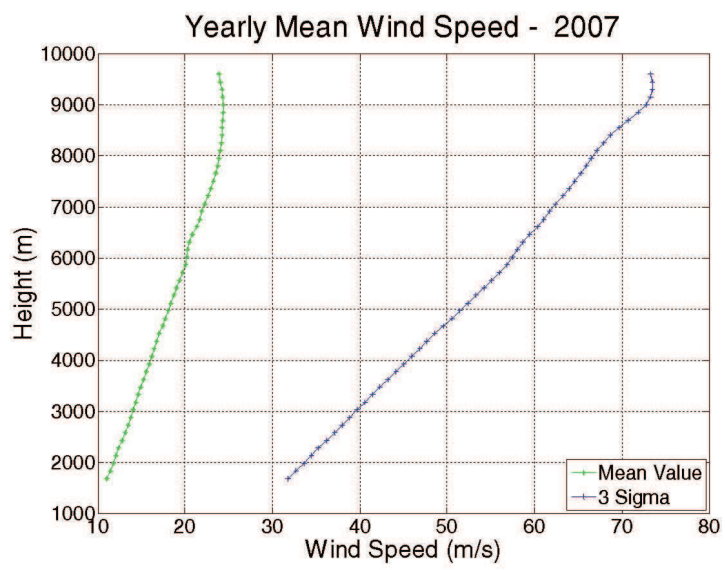

Fig. 4. Wind speed variation with altitude, year mean and 3 sigma values shown

Fig. 4 shows the mean wind speed and the 3 sigma value, and it is possible to notice that at $6 \mathrm{~km}$ altitude these values are $20 \mathrm{~m} / \mathrm{s}$ and $55 \mathrm{~m} / \mathrm{s}$ respectively.

Another factor to be considered is that, in the time domain the wind speed is quite variable with relatively rapid transients (i.e. gusts). As discussed in Aglietti, 2009 the tethered aerostat is a non-linear system, with considerable damping, and therefore rapid transients of the input in reality produce a response that is significantly lower than what is calculated simply using the maximum wind speed in a static analysis. 


\section{Concept design}

\subsection{Tethered aerostat}

For an aerostat to support PV devices, this has to be able to produce enough lift via its buoyancy to overcome its weight, the weight of the solar cells plus any control system and that of the tether, still leaving enough margin to produce an appropriate tension in the tether to avoid excessive sag.

Neglecting any aerodynamic lift which could be generated by the shape of the Aerostat, the lifting force due to the aerostat buoyancy is:

$$
B=\left(\rho_{\text {air }}-\rho_{\text {gas }}\right) \mathrm{gVol}
$$

where $\mathrm{Vol}$ is the volume of the aerostat and $\rho_{\text {air }}$ and $\rho_{\text {gas }}$ the densities of air and gas (helium or hydrogen can be used) filling the aerostat envelop at the specific conditions of operations (e.g. pressure, altitude), and $g$ is the gravity acceleration $\left(9.81 \mathrm{~m} / \mathrm{s}^{2}\right)$. Here it is assumed that there is a negligible pressure differential between inside and outside the aerostat envelope, and for simplicity is also taken that the whole volume of the envelope is occupied by the gas (i.e. ballonets for altitude control completely empty).

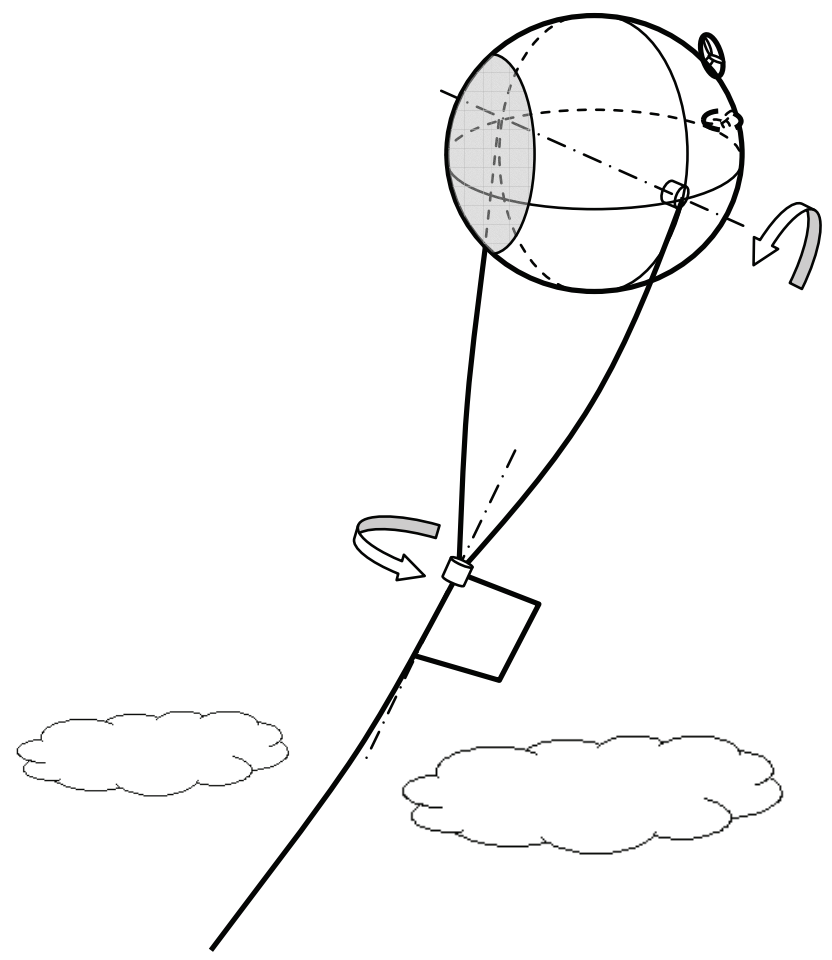

Fig. 5. Schematic configuration of an Aerostat for Electrical Power Generation, as a gimballed tethered balloon - the grey area represents PV cells cladding.

Typically aerostats have streamlined bodies to reduce the aerodynamic drag, however when such shaped aerostats are moored they then tend to rotate to the oncoming flow direction 
like a weathervane. Here the aerostat is required to maintain its orientation towards the Sun, therefore a spherical shape pointed through a system of gimbals seems more appropriate (see Fig. 5). A spherical aerostat generates more aerodynamic drag and clearly would require a more substantial structure and tether, but these issues can be tackled by its structural design (Miller \& Nahon, 2007). A tethered sphere also suffers substantial vortex induced vibrations (Williamson \& Govardhan, 1997). However a previous study (Aglietti, 2009) has shown that due to the non-linearity of the structural problem (mainly the sag of the tether) and the very slow frequency response characterized by a high value of damping, the force oscillations in the tether line (produced by relatively rapid force transients, e.g. gusts) are relatively small. The resultant rotations of the aerostat are only a few degrees which in turn produces a drop in the energy production of less than $1 \%$.

Given its spherical shape, from the volume it is possible to calculate the surface area, and from this, taking an appropriate material area density, it is possible to estimate the weight of the envelope. The area density of the material for the skin can then be increased by $33 \%$ as suggested in (Khoury \& Gillett, 2004), to account for the weight of various reinforcements, support for the payload etc.

With a similar approach the weight of the PV cells can be estimated by the surface covered, and assuming that a fraction $\gamma$ of the whole aerostat envelope is covered by the cells, knowing the area density of the cells (also here including wiring etc), it is possible to estimate the weight of the cells. Therefore the weight of aerostat and PV devices can be written as:

$$
W_{\text {Aero }}=\left(1.33 \delta_{\text {aero }}+\delta_{\text {cells }} \gamma\right) g 4 \pi \mathrm{R}^{2}
$$

where $\delta_{\text {aero }}$ and $\delta_{\text {cells }}$ are the area density of the envelope material and PV cells respectively, $\gamma$ is the fraction of the envelope surface that is covered by the PV cells, $g$ is gravity acceleration and $\mathrm{R}$ is the radius of the balloon.

To assess the weight of the tether it is necessary to estimate the weight of the electrical conductors (taken as aluminum for this high conductivity over mass ratio) plus that of the strengthening fibers (e.g. some type of Kevlar). The size of the required conductor can be estimated from the electrical current (that is the ratio between the power generated by the $\mathrm{PV}$ devices on the aerostat and the transmission voltage) and setting the electrical losses permitted in the cable to a specific value. Therefore the cross section of the conductor will be

$$
A_{\text {cond }}=r_{A l} \frac{S}{\eta_{\text {trans }}} \frac{P_{\text {gen }}}{V^{2}}
$$

where $r_{A l}$ is the resistivity of the aluminum, $S$ is the overall length of the conductor, $\eta_{\text {trans }}$ is the ratio between the power lost in the cable and that generated by the PV devices (that is $\left.\mathrm{P}_{\text {gen }}\right)$, and $\mathrm{V}$ is the voltage.

The power generated by the PV system can be estimated from the area covered by the cells (that is a fraction $\gamma$ of the whole aerostat surface), their efficiency ( $\left.\eta_{\text {cells }}\right)$, an efficiency parameter $\left(\eta_{\text {area }}\right)$ that considers that the cells are on a curved surface and therefore the angle of incidence of the sun beam varies according to the position of the cells and finally the solar flux $\Phi$ at the aerostat operational altitude that is the irradiance discussed in the previous sections: 


$$
P_{\text {gen }}=4 \pi \mathrm{R}^{2} \gamma \eta_{\text {cells }} \eta_{\text {area }} \Phi
$$

Finally the weight of the conductor will be its cross sectional area multiplied by length and by its specific weight (density times g), so substituting equation (6) in (5) the weight of the conductor can be written as:

$$
W_{\text {cond }}=\delta_{A l} g r_{A l} \frac{S^{2}}{\eta_{\text {trans }}} \frac{4 \pi \mathrm{R}^{2} \gamma \eta_{\text {cells }} \eta_{\text {area }} \Phi}{V^{2}}
$$

The weight of the reinforcing fibres can be calculated from the strength necessary to keep the aerostat safely moored.

The maximum tensile force on the tether can be calculated as:

$$
T=\sqrt{\left(B-W_{\text {Aero }}\right)^{2}+D^{2}}
$$

where $\mathrm{D}$ is the aerostat drag force, equal to:

$$
D=\frac{1}{2} \rho_{\text {air }} \nu^{2} C_{d} \pi R^{2}
$$

In the above expression $v$ is the maximum wind velocity and $C_{d}$ is the drag coefficient. From the maximum expected tension in the tether, knowing the fibres strength $\left(\sigma_{u}\right)$ it is possible to calculate the required cross section and from that the weight of the reinforcing fibres.

$$
W_{f i b}=\delta_{f i b} S_{T} \frac{T}{\sigma_{u}}
$$

where $\delta_{\mathrm{fib}}$ is the density of the fibers and $\mathrm{S}_{\mathrm{T}}$ the length of the tether.

So that the overall weight of the tether will be:

$$
W_{\text {Tether }}=\delta_{\text {cond }} g r_{\text {cond }} S^{2} \frac{\eta_{\text {cells }} \eta_{\text {area }} A_{\text {cells }} \Phi}{\eta_{\text {trans }} V_{\text {gen }}^{2}}+\delta_{\text {fib }} S_{T} \frac{T}{\sigma_{u}}
$$

Aerodynamic forces will also act on the tether line, and they will produce further sagging (see Aglietti, 2009). However this effect does not modify significantly the maximum tension in the tether that will still be at the attachment between the balloon and the tether (equation 8).

\subsection{Engineering parameters}

In the previous sections, the equations that govern the preliminary sizing of the aerostatic platform have been derived and these equations can be combined, for example, to design a facility with a specified power output. Overall, as the lift and the weight are proportional to the aerostat volume and surface respectively, it will always be possible to design an aerostat large enough to "fly". Here the volume as been set at $179,000 \mathrm{~m}^{3}$ (that is a $35 \mathrm{~m}$ radius sphere) which gives a suitable ratio between lift and drag (using helium as a gas filler would give a buoyancy of $1 \mathrm{MN}$ ). 
In order to reduce the interference with the aviation industry and international air traffic the maximum altitude will be set to $6 \mathrm{~km}$.

The values of the specific engineering parameters which appear in the equations (like for example the area density of the skin) have a crucial role in defining the size of the aerostat. In this section realistic and sometimes conservative values for these parameters will be discussed and utilized in the equations to size a viable platform.

Starting with the solar cells, there are various types available on the market. These range from light weight amorphous silicon triple junction cells (with an efficiency of up to $7 \%$ ) that could be directly integrated on the skin (see for example Amrani et al., 2007), with a mass penalty that could be as low as $25 \mathrm{~g} / \mathrm{m}^{2}$, to heavier but more efficient cells (e.g. TripleJunction with Monolithic Diode High Efficiency Cells (www.emcore.com) efficiency 28\%), which require some rigid backing and could be used with a mass penalty that can be in the region of $850 \mathrm{~g} / \mathrm{m}^{2}$. These types of cells could be mounted on light weight carbon fibre reinforced plastic tiles that would be used to clad part of the aerostat envelope. Although amorphous silicon cells seem more appropriate, judging by the efficiency over area density ratio, there are issues concerning the ease of installations, repairs, amount of surface available and finally costs that have to be considered. In this study, an efficiency of $15 \%$ and an overall area density of the PV cells $\delta_{\text {cells }}$ (including connectors etc.) of $1 \mathrm{~kg} / \mathrm{m}^{2}$ will be considered.

Taking a maximum peak solar irradiation of $1.2 \mathrm{~kW} / \mathrm{m}^{2}$, from the equations in the previous section it is possible to calculate $W_{\text {Aero }}\left(18.9 \times 10^{3} \mathrm{~kg}\right)$ and the peak power generated $(\sim 0.5$ MW). However to size the conductor in the tether it is necessary to set a transmission voltage $\mathrm{V}$, and this should be high enough in order to reduce the losses in the cable. One option is to connect the solar arrays to obtain a voltage in the region of $500 \mathrm{~V}$ DC and use a converter to bring it up to a few $\mathrm{kV}$. However the converter will introduce some electrical losses and its weight might be an issue as it has to be supported by the aerostat (although the weight of the converter might be compensated by a lighter cable). The other option is to "simply" connect identical groups of solar arrays in series, to maintain the same current and obtain a DC voltage in the region of $1.5-3 \mathrm{kV}$. The solar panels would be provided with bypass and blocking diodes and other circuitry that might be necessary to protect the elements of the system. Setting the transmission voltage at $3 \mathrm{kV}$ and allowing for $5 \%$ electrical losses in the cable (i.e. $\eta_{\text {trans }}=0.05$ ) enables the cross section of the aluminium conductor and its weight to be calculated as $388 \mathrm{~mm}^{2}$ and $13.0 \times 10^{3} \mathrm{~kg}$ respectively.

Using the results in the previous section and taking a maximum wind speed of $55 \mathrm{~m} / \mathrm{s}$ (3 sigma value) and using equation 9 it is possible to calculate the weight of the fibres as $2.7 \times 10^{3} \mathrm{~kg}$, so that the overall weight of the tether will be $15.7 \times 10^{3} \mathrm{~kg}$. It should be stressed that the $55 \mathrm{~m} / \mathrm{s}$ value is quite conservative, in fact this corresponds to the peak wind speed during a gust and due to the highly non linear behaviour of the tether system (see Aglietti, 2009) the force in the tether will be considerably smaller. On the other hand this level of conservatism is more than justified by the catastrophic effect that the tether rupture would have.

\section{Conclusion}

This chapter has investigated the possibility of using a high altitude aerostatic platform to support PV modules to increase substantially their output by virtue of the significantly enhanced solar radiation at the operating altitude of the aerostat. 
Although the figures presented for the analysis of the radiation have been obtained for a specific set of data relative to a well defined location in the UK (and the calculations presented involve some approximations, justified by the preliminary character of the analysis). The results obtained illustrate the advantages, in terms of irradiation, of collecting solar energy between $6 \mathrm{~km}$ and $12 \mathrm{~km}$ altitude, rather than on the ground. The general conclusions can be extended, with a certain degree of approximation, to other countries at the same latitude and with similar climates.

Based on realistic values for the relevant engineering parameters that describe the technical properties of the materials and subsystems, a static analysis of the aerostat in its deployed configuration has been carried out. The results of the computations, although of a preliminary nature, demonstrate that the concept is technically feasible.

As the AEPG requires minimum ground support and could be relatively easily deployed, there are several applications where these facilities could be advantageous respect to other renewables.

It is acknowledged that the concept mathematical model and its concept design are of a preliminary nature. However they do indicate that there is the potential for a new facility to enter the renewable energy market, and further work should be carried out to investigate this possibility more in depth.

\section{References}

Aglietti, G.S. (2009). Dynamic Response of a High Altitude Tethered Balloon System. AIAA Journal Of Aircraft, Vol. 46, No. 6, page 2032-2040, doi: 10.2514/1.43332, November-December 2009.

Aglietti, G.S.; Markvart, T.; Tatnall, A.R. \& Walker S.J.I. (2008). Aerostat for Electrical Power Generation Concept feasibility. Proceedings of the IMechE Part G; Journal of Aerospace Engineering, Vol 222, pp 29-39, ISBN0954-4100; DOI: 10.1243/09544100JAERO258 Feb 2008.

Aglietti, G.S.; Markvart, T.; Tatnall, A.R. \& Walker S.J.I. (2008) Solar Power Generation Using High Altitude Platforms Feasibility and Viability. Progress in Photovoltaics: Research and Applications, Vol. 16 pp 349-359, 2008.

Badesha, S.S. (2002). SPARCL: A high-altitude tethered balloon-based optical space-toground communication system, Proceedings of the SPIE - The International Society for Optical Engineering, Volume 4821, 2002, ISSN: 0277-786X.

Bely, P., \& Ashford, R. L. (1995). High-altitude aerostats as astronomical platforms, Proceedings of SPIE - The International Society for Optical Engineering, Volume 2478, 1995, Pages 101-116.

Berk, A.; Bernstein L.S. \& Robertson, D.C. (1989). MODTRAN: A moderate resolution model for LOWTRAN 7, Report GL-TR-89-0122, Geophysics Laboratory, Air Force Systems Command, United States Air Force, Hanscom, AFB, MA 01731

Colozza, A. \& Dolce, J.L. (2005). High-Altitude, Long-Endurance Airships for Coastal Surveillance, NASA Technical Report, NASA/TM-2005-213427, 2005.

Dick, H.G. \& Robinson, D.H. (1992). The Golden Age of the Great Passenger Airships: Graf Zeppelin and Hindenburg, Prentice Hall \& IBD; ISBN-13: 978-1560982197, Nov 1992.

Donovan, D. \& Van Lammeren A. (2001). Cloud effective particle size and water content profile retrievals using combined lidar and radar observations 1 . Theory and examples. Journal of Geophysical Research. 106, 27425-27448. 
El Amrani, A.; Mahrane, A.; Moussa, F. Y. \& Boukennous, Y. (2007). Solar Module Fabrication. International Journal of Photoenergy, Vol. 2007, Article ID 27610

Glaser, P.E.; Maynard, O.E.; Mackovciak, J. \& Ralph, E.L., Arthur D. Little, Inc., Feasibility study of a satellite solar power station, NASA CR-2357, NTIS N74-17784, Feb. 1974

Gueymard, C.A. (1995). SMARTS, A Simple Model of the Atmospheric Radiative Transfer of Sunshine: Algorithms and Performance Assessment. Technical Report No. FSECPF-270-95. Cocoa, FL: Florida Solar Energy Center.

Jackson, B. (1996). A software power model for a spin-stabilized LEO spacecraft utilizing V/T charge control. Proceedings of the Aerospace Applications Conference IEEE. 3. 219227.

Khoury G.A. \& Gillett J.D., (2004). Airship Technology, Cambridge Aerospace Series, Edited by Gabriel A. ISBN-10: 05216075312004.

Kirschner, E.J. (1986). Aerospace Balloons: From Montgolfiere to Space, pp. 21, TAB Books, Inc., Blue Ridge Summit, Pennsylvania, 1986.

Kurokawa, K. (2004). Energy from the Desert: Feasibility of Very Large Scale Photovoltaic Power Generation (VLS-PV) Systems, Earthscan Publications Ltd, ISBN-10: 1902916417, May 2004

Liou, K.N. (2002). An Introduction to Atmospheric Radiation, second ed. Elsevier Science

Mankins, J.C. (1997) A Fresh Look at Space Solar Power: New Architectures, Concepts and Technologies, Proceedings of the 38th International Astronautical Congress, IAF paper no IAF-97-R.2.03, 1997.

Markvart, T. \& Castañer, L. (2003). “Practical Handbook of Photovoltaics: Fundamentals and Applications", Elsevier, Oxford.

Mayer B. \& Kylling A. (2005). Technical note: The libRadtran software package for radiative transfer calculations - description and examples of use. Atmos. Chem. Phys. 5, 1855-1877.

Miller J.I. \& Nahon M. (2007). Analysis and Design of Robust Helium Aerostats. AIAA Journal of Aircraft, Vol. 44, No. 5, pp. 1447-1458, 2007

Redi S.; Aglietti, G.S.; Tatnall A.R.; Markvart T. (2009) An Evaluation of a High Altitude Solar Radiation Platform ASME-Journal of Solar Energy Engineering - in print.

Roberts, B.W.; Shepard, D.H.; Caldeira, K.; Cannon, M.E.; Eccles, D.G.; Grenier, A.J. \& Freidin, J.F. (2007). Harnessing High-Altitude Wind Power, IEEE Transactions On Energy Conversion, Vol. 22, No. 1, March 2007.

Robinson, D.H. (1973). Giants in the Sky: A History of the Rigid Airship, University of Washington Press ISBN-13: 978-0295952499, 1973.

Williamson, C.H.K. \& Govardhan, R.G. (1997). Dynamics And Forcing Of A Tethered Sphere In A Fluid Flow, Journal of Fluids and Structures (1997) 11, 293 - 305

http://rosaerosystems.pbo.ru/english/products/puma.html, accessed 25/09/09

http://www.cloud-net.org/, accessed 25/09/09

http://www.emcore.com/assets/ photovoltaics/btjm.solar.ds.pdf, accessed 25/09/09

http://www.magenn.com/news.php, accessed 25/09/09

http://www.tcomlp.com/aerostats.html, accessed 25/09/09 


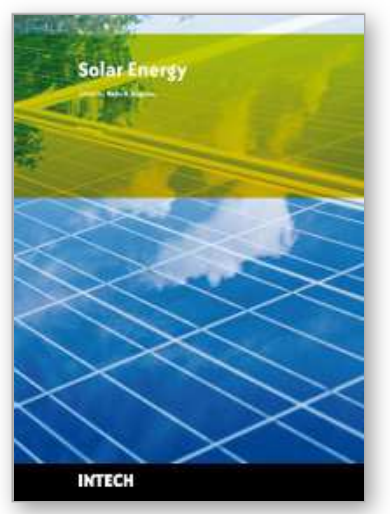

\author{
Solar Energy \\ Edited by Radu D Rugescu
}

ISBN 978-953-307-052-0

Hard cover, 432 pages

Publisher InTech

Published online 01, February, 2010

Published in print edition February, 2010

The present "Solar Energy" science book hopefully opens a series of other first-hand texts in new technologies with practical impact and subsequent interest. They might include the ecological combustion of fossil fuels, space technology in the benefit of local and remote communities, new trends in the development of secure Internet Communications on an interplanetary scale, new breakthroughs in the propulsion technology and others. The editors will be pleased to see that the present book is open to debate and they will wait for the readers' reaction with great interest. Critics and proposals will be equally welcomed.

\title{
How to reference
}

In order to correctly reference this scholarly work, feel free to copy and paste the following:

G. S. Aglietti, S. Redi, A. R. Tatnall, T. Markvart and S.J.I. Walker (2010). Aerostat for Solar Power Generation, Solar Energy, Radu D Rugescu (Ed.), ISBN: 978-953-307-052-0, InTech, Available from: http://www.intechopen.com/books/solar-energy/aerostat-for-solar-power-generation

\section{INTECH}

open science | open minds

\author{
InTech Europe \\ University Campus STeP Ri \\ Slavka Krautzeka 83/A \\ 51000 Rijeka, Croatia \\ Phone: +385 (51) 770447 \\ Fax: +385 (51) 686166 \\ www.intechopen.com
}

\author{
InTech China \\ Unit 405, Office Block, Hotel Equatorial Shanghai \\ No.65, Yan An Road (West), Shanghai, 200040, China \\ 中国上海市延安西路65号上海国际贵都大饭店办公楼405单元 \\ Phone: +86-21-62489820 \\ Fax: +86-21-62489821
}


(C) 2010 The Author(s). Licensee IntechOpen. This chapter is distributed under the terms of the Creative Commons Attribution-NonCommercialShareAlike-3.0 License, which permits use, distribution and reproduction for non-commercial purposes, provided the original is properly cited and derivative works building on this content are distributed under the same license. 